\title{
Mohini: A Case Study of a Transnational Spiritual Space in the History of the Theosophical Society
}

\author{
Mriganka Mukhopadhyay \\ University of Amsterdam, Amsterdam, The Netherlands \\ mrigankamukhopadhyay@gmail.com
}

\begin{abstract}
This essay investigates the well-known, yet understudied, Bengali Theosophist Mohini Mohun Chatterji. In this essay, Mohini Chatterji's life and career will be discussed in relation to the Theosophical Society. His case will be seen as an example of how Bengali Theosophists played a significant role in the transcultural, entangled history of the global Theosophical movement, thus connecting Vedantic philosophy with occultism.
\end{abstract}

\section{Keywords}

Bengal Theosophical Society - Bhagavad Gita - Vedanta - W. B. Yeats

Mahatma K. H. sends his chela, under the guise of Mohini Mohun Chatterjee, to explain to the London Theosophists of the Secret Sectionevery or nearly every mooted point and to defend you and your assumptions. You better show Mohini all the Master's letters of a non-private character - saith [sic] the Lord, my Boss — so that by knowing all the subjects upon which he wrote to you he might defend your position the more effectually - which you yourself cannot do, not being a regular chela. Do not make the mistake, my dear boss, of taking the Mohini you knew for the Mohini who will come.

H. P. BLAVATSKY's letter to A. P. SINNETT, 18 January, 1884 
On 20 February 1884, the founders of the Theosophical Society, Madame Helena Petrovna Blavatsky (1831-1891) and Colonel Henry Steel Olcott (1832-1907), set sail for Marseilles from the shores of Bombay (Olcott 1904: 73). This was their first trip to the West after setting up the headquarters of the Theosophical Society in Adyar, Madras (now Chennai), in 1882. On this occasion they were accompanied by two young Indian Theosophists, a wealthy 20 -year-old Parsi graduate from Bombay (now Mumbai) called Burjorji Jamsapji Padshah (1864-1941), and a 26-year-old lawyer from Calcutta (Kolkata) named Mohini Mohun Chatterji (1858-1936). Chatterji was a Bengali Theosophist who would go on to become Madame Blavatsky's blue-eyed boy, influence the Western occult world with lightning speed, and then disappear from the Theosophical circle after falling from Blavatsky's grace. What follows in this article is a case study of this fascinating Bengali Theosophist and the socio-intellectual world he inhabited.

The purpose of the case study is to examine the history of the Theosophical Society in a transnational context. I shall mainly focus on Mohini Chatterji's engagement with the Theosophical movement and proceed by addressing three related questions. First, how does Chatterji as an individual agent connect Indian spirituality and occultism in a transnational context? Second, what role did his philosophical discourses play in preparing the stage for Swami Vivekananda's much more widely influential propagation of Vedanta in the West? Third, as an Indian theosophist, how did Mohini's discourses differ from Blavatsky's own Theosophical agenda? Methodologically, this essay will take an empirical-historical approach while constructing a biographical account of Mohini Chatterji's Theosophical career. In the study of modern esotericism and occultism, what makes Chatterji important is his position as an agent of an entangled history of Theosophy. My aim is to identify Chatterji as an important figure in the transcultural intellectual history of religion in modern times.

A note about orthography: Mohini Mohun Chatterji's name appears in various forms in the historical sources, e.g., "Mohini Mohun Chatterji," "Mohini Mohan Chatterjee," "Mohini Mohan Chattopadhyaya," "Mohini Mohun Chattopadhyay," and so on. ${ }^{1}$ Such variations of the forms and spellings are common for most Bengali names, although they can mislead those who are unfamiliar with the Bengali language into believing that the names refer to

1 In fact, one of the sources also mentions that he used the pseudonym (http://theosophy .wiki/w-en/index.php?title=Mohini_Mohun_Chatterji; accessed, 23June 2018). However, the authenticity of this information cannot be verified. In fact, there was a Bengali Theosophist whose name was J. C. Chattopadhyaya who was employed by the princely state of Kashmir. Chattopadhyaya published significant works on Kashmiri Shaivism and travelled extensively in Europe and North America. 
different historical personages. In this article, I will use the most common form of the name, Mohini Chatterji. Some Theosophical literature referred to him only by his first name, Mohini, an indication of his affection and close proximity to Blavatsky at the highpoint of his Theosophical career.

Mohini Chatterji came from the rich socio-cultural milieu of nineteenthcentury Calcutta, known in the historiography of India as the Bengal Renaissance. ${ }^{2}$ His mother, Chandrajyoti Devi, was the granddaughter of Ram Mohan Roy, the early leading intellectual of modern India. ${ }^{3}$ His wife, Saroja Devi, daughter of Dwijendranath Tagore, was the niece of the famous Indian poet Rabindranath Tagore (1861-1941). Chatterji was three years older than Rabindranath and so belonged to the same generation in Bengal's cultural milieu. Chatterji was himself a follower of the Adi Brahmo Samaj, the oldest Brahmo sect, led by Rabindranath Tagore's father and Chatterji's grandfatherin-law, Debendranath Tagore (1817-1905). Mohini made his affiliation clear in an American newspaper when he stated, "I am [a] member of the Brahmo somaj [sic], as well as a member of the Theosophical Society" (Boston Post 1886), but his Brahmo identity was often overlooked, and Western newspapers frequently mentioned him as an Indian Brahmin (Pall Mall Gazette 1891: 2; Liverpool Mercury 1884). In a couple of instances, the British press even erroneously identified him as a Buddhist who came to convert Europe into Buddhism (Shields Daily Gazette and Shipping Telegraph 1888, Nottingham Evening Post 1887). (Shields Daily Gazette and Shipping Telegraph 1888, Nottingham Evening Post 1887). Later scholarship has followed these Euro-American textual sources

2 The label "Bengal Renaissance" developed in the postcolonial historiography of India; see Sen 1946, Kopf 1969, Sarkar 1979. The label is still in use in some recent scholarship; see Travers 2007, Dasgupta 2009.

3 Although it is quite certain that Chatterji was a descendant of Raja Ram Mohan Roy, I have not found any textual source that mentions Chatterji's exact relation to Roy. Professor Monojit Chatterji, Chatterji's great-grandson, has confirmed for me that Roy's daughter was the grandmother of Chatterji (interview with Monojit Chatterji at Cambridge, 4 October 2017). Mrs. Rita Bandyopadhyay, Chatterji's great-granddaughter, gave me a detailed account of Chatterji's family background. As Chatterji's father, Lalit Mohun Chatterji, married into the family of the Brahmo leader Ram Mohan Roy, he was ostracized by orthodox Hindu society. As a result, the Chatterji family grew closer to Roy and became influenced by Brahmo rituals and customs. They gave up the Hindu practice of image worship and were strongly influenced by Advaita Vedantic ideals. Mohini Chatterji officially became a Brahmo when he married into the Tagore family (interview with Rita Bandyopadhyay at Kolkata, 16 January 2018). 
and described him only as a Brahmin. ${ }^{4}$ Among others, the famous Irish poet and occultist William Butler Yeats was instrumental in fanning this misconception when he identified Chatterji as an Indian Brahmin (Yeats and Wade 1908: 196; Yeats 1958: 250-251). Although "Chatterji" or "Chattopadhyay" is a Brahmin surname, the members of the Brahmo Samaj did not consider themselves to be part of the Hindu caste system, nor did they identify themselves as "Brahmins." As we will see later, Chatterji's association with the Brahmo Samaj and the consecutive Brahmo Vedantic ideals had a major impact on his spiritual discourses. Therefore, it is important to keep Mohini's Brahmo identity in mind when discussing him in the context of Theosophy and occultism. ${ }^{5}$

\section{$2 \quad$ First Brush with Theosophy}

Not much is known about Chatterji's early life except that he graduated as a lawyer from the University of Calcutta. The earliest mention of him appears in the Membership Register of the Theosophical Society. According to the register, on 6 April 1882 Chatterji - then a resident of 102 Manicktollah Street, Calcutta - became the 1066th member of the Theosophical Society; ${ }^{6}$ the Bengal Theosophical Society was established in Calcutta on the same day. Twelve other members joined alongside him, including: Narendro Nath Sen, the editor of the Indian Mirror newspaper who later became the President of the Bengal Theosophical Society; Janaki Nath Ghosal, Congress leader from Bengal and son-in-law of Debendranath Tagore and so also related to Mohini Chatterji; and Matilal Ghose, later editor of the Amrita Bazar Patrika newspaper. ${ }^{7}$

Chatterji rose very rapidly to prominence among the Bengali Theosophists; already on 14 April 1882 he was appointed its Assistant Secretary (Olcott 19oo: 343). Blavatsky herself was present in Calcutta in April 1882 and closely monitored all the events concerning the setting up of the Theosophical movement

4 Most published academic works identify Chatterji as a Brahmin and ignore his Brahmo identity; cf. Dixon 2001: 30-31; Bachchan 1965: 18; Akai: 1997: 77.

5 It is important to emphasize that Chatterji identified himself as a Brahmo and not as Brahmin. The Brahmos did not perceive themselves as part of the Hindu caste system, so there is no question of identifying Chatterji as a mere Brahmin. For Brahmo Samaj, see Kopf 1979 .

6 See Membership Register of the Theosophical Society, Book 1 A, http://tsmembers.org/ (accessed 5 October 2017).

7 Ibid. 
in Bengal. ${ }^{8}$ In these early years of the Theosophical movement in India, Blavatsky seems to have been quite eager to recruit young Indians. She was especially keen on showing the world that her Oriental pupils were spiritually gifted and extremely interested in Theosophy. To some extent, these young Indian Theosophists were promoted as the poster-boys of Theosophy in India and frequently appeared in group photographs with Blavatsky and Olcott.

Besides Chatterji, two other prominent young Indian Theosophists were Damodar Mavalankar (1857-1885) and T. Subba Row (1856-189o). These three young men were contemporaries and featured prominently in the Theosophical literature of the mid-188os. One of Blavatsky's biographers writes that Blavatsky had taken "small note" of Chatterji in Calcutta. At that time she was more interested in Subba Row (Meade 1980: 249), a Tamil Theosophist from Madras who helped the founders in setting up the newly formed headquarters of the Theosophical Society in Adyar (Olcott 1900: 292) and who also "exhibited a lively initial interest" in Theosophy (Meade 1980: 249). This does not, however, necessarily indicate that Chatterji was of any lesser significance. On the contrary, almost immediately after his admittance to the Theosophical Society, he became part of Blavatsky's coterie, as is evident from the fact that Chatterji joined Blavatsky's small entourage when she left for Darjeeling after the establishment of the Bengal Theosophical Society.

Darjeeling - a popular Himalayan hill station located in northern Bengal - was significant for Theosophists because of its proximity to Tibet, the alleged abode of the Theosophical Masters (the Mahatmas), and as a result has a special importance in the history of the Theosophical Society. It seems that the group spent the summer of 1882 there (Olcott 1900: 391), and eighteen months later, in December 1883, Chatterji published an article, “The Himalayan Brothers - Do they Exist?" in The Theosophist, stating his views on the Theosophical Masters and the so-called Great White Brotherhood of Tibet. In this article, Chatterji claimed that he met some of the followers of Master Koot Hoomi and was very much convinced of the existence of the Mahatmas (Chatterji 1883: 115-118).

Mohini Chatterji gradually became prominent in the Theosophical circle of Calcutta. Young and energetic, he was entrusted with several activities. For instance, he prepared and read the annual report of the Bengal Theosophical Society during its first anniversary in 1883 (The Theosophist 1883: 1-2). More

8 Although Blavatsky personally did not attend the establishment of every branch in India and left the business to Olcott, she made sure to remain present during the foundation ceremony of the Bengal Theosophical Society. She considered Calcutta to be a very significant base for her movement (Mukhopadhyay 2016: 111-112). 
importantly, when Colonel Olcott established the first Sunday School of the Theosophical Society in Calcutta on 10 March 1883 , Chatterji was appointed as the chief teacher. This was a religious school set up for Indian children, and it enrolled a total of seventeen children in its first year (Olcott 1900: 412). It was one of the earliest initiatives in the Theosophical Society's involvement with the Indian education system, an involvement that would become quite extensive in later years. ${ }^{9}$ On 4 March 1883 , within a year of Chatterji's admittance, his father, Lalit Mohun Chatterji, also joined the Theosophical Society, although he later discontinued his membership. ${ }^{10}$ Eventually, Mohini also became involved in Spiritualism and took part in the séances arranged by the members of the Tagore family. ${ }^{11}$ One of his frequent partners in these activities was his sister-in-law, Swarnakumari Devi, wife of Janaki Nath Ghosal and the first Bengali woman to become a Theosophist (Chaudhurani 2007: 68-71).

Over time, Chatterji strengthened his relationship with Blavatsky and accompanied her on some of her tours to various parts of India. Blavatsky was so impressed with him that she planned to appoint him as her secretary after his return from the European trip (Blavatsky 1975: 56). Just before their departure for Europe in 1884 , Blavatsky and Chatterji went to Wadhwan in Gujarat in western India along with a few other Theosophists. From Wadhwan, they traveled to Bombay for boarding the ship to France. It was around this time, in 1883-1884, that Chatterji started being identified as the Chela of Master Koot Hoomi.

"Chela" has been one of the most important concepts in Theosophical discourse. Of Sanskrit origin, the word means a dedicated disciple or a pupil who serves his teacher with great loyalty. In 1883, Blavatsky wrote an article, "Chelas and Lay Chelas," that was published in the July issue of The Theosophist. She claimed that the term Chela was introduced "by Theosophy into the nomenclature of Western metaphysics," and she defined it as "one who has offered himself or herself as a pupil [to a Guru or an Adept] to learn practically the 'hidden

In time, the Theosophical Society would become one of the biggest patrons of education in India, ultimately setting up Central Hindu College (now Central Hindu School) in Benares under the supervision of Annie Besant.

10 Membership Register of the Theosophical Society, Book 1 A, http://tsmembers.org/ (accessed 20 July 2018).

11 Mrs. Rita Bandyopadhyay has informed me that the séance sessions were performed even later by Chatterji's grandchildren in their house at 33 McLeod Street, Calcutta. 
mysteries of Nature and the psychical powers latent in man." However, she further claimed that although one has to apply for the candidature of Chela-ship, the "Himalayan Masters" themselves select the Chelas from a considerable group of "natural mystics." She then entwined this Indian concept with Western esoteric traditions by identifying Paracelsus, Robert Fludd, and Pico della Mirandola as Western Chelas selected by the Tibetan Adepts. According to her, these esotericists never applied for Chela-ship, but their "temperamental affinity to this celestial science more or less forced the distant Adepts to come into personal relations with them." In the same article she also outlined seven qualifications for becoming a Chela: perfect physical health, mental and physical purity, unselfishness, truthfulness and faith in the law of Karma, intuition of oneself as Divine Atman, celibacy, and calm indifference (Blavatsky: 1883: 6o6-614).

This article was published at a time when Mohini Chatterji was gradually becoming closer to Blavatsky and Olcott. As he became one of the prominent Indian Theosophists, he quickly became honored as a Chela of the Master Koot Hoomi. This status can be seen as a sort of promotion within the Theosophical hierarchy - a reward for his growing devotion to the leaders of the Society and his dedication to Theosophy. Mohini's increasing importance as a Chela can be seen in a number of mysterious letters that were sent to the eminent Theosophist A. P. Sinnett (1840-1921), allegedly by the Masters. References to Mohini can be found in Letters 61, 62, 63, 64, 65, 66, 72 84, 117, 139, 140, and 141, among others.

For instance, Mahatma Letter 117 - sent to Sinnett - refers to Chatterji as "lay Chela No. 2" (Barker 1924: 450). Similarly, in Letter 84, an undated letter informing Sinnett that Olcott would remain as his guest during his visit to Britain, there are specific instructions about Chatterji; the letter, signed by "K. H.," apparently Master Koot Hoomi, states, "[Olcott] will be accompanied by Mohini, whom I have chosen as my chela and with whom I sometimes communicate directly. Treat the boy kindly, forgetting he is a Bengalee [sic], and only remembering he is now my Chela" (397-398). The emphasis in the last part of the sentence shows that Chatterji was considered a very important associate of the Theosophical authorities, whether by the historical leader (Blavatsky) or the semifictional Mahatmas. It is also noteworthy that this portion of the letter points out Chatterji's identity as a Bengali. The mention of Chatterji's regional identity showed that he was unique among all other Theosophists present in Britain at that time. Although we find the names of many other Indians throughout the entire volume of the Mahatma Letters, no other ethnic or linguistic identity has been highlighted while commenting on them. 
It is interesting to note that while Chatterji's importance as a Chela is mentioned, he is not identified as a Hindu or an Indian Theosophist but rather as a Bengali Theosophist. His example shows that the Theosophical Society gave a great deal of attention to the Bengali Theosophists from very early on in its history. Indeed, Chatterji was himself also very much conscious of his identity within the Theosophical Society. While co-authoring the book, Man: Fragments of Forgotten History, with Laura Holloway, Chatterji identified himself as "The Eastern Chela" in contrast to Holloway, who identified herself as "The Western Chela" (Chatterji and Holloway 1893: ix, xv). Chatterji's actions and words during his stay in the United Kingdom indicated a conscious expression of Oriental identity in several ways, and when his skin color and ethnicity are being highlighted (Barker 1924: 397-398), one cannot overlook the racial dimensions. A large part of the Theosophical movement's history has scars of subtle racial ideas that are yet to be adequately addressed in scholarly discussions. The racial mindset of Blavatsky and her colleagues needs to be studied in greater detail in connection to the Theosophical Society's Orientalism.

It was, however, not only Chatterji's attitude and body language that became a point of curiosity for the European press and the Theosophical circle; his writings and lectures on Indian philosophy and spirituality also attracted a large audience. In the following section, I will discuss how this Oriental identity gave Chatterji a powerful voice as an Indian Theosophist within the Theosophical Society. His Indian-ness as well as his Bengali identity will give us a picture of how multilayered the Theosophical Society was.

"Men Gazed upon Mohini with Awe, and Ladies with Enthusiasm"12

Mohini Chatterji became popular among the European occultists almost as soon as he arrived in March $1884 .{ }^{13}$ His persona appealed to Westerners for many reasons. Europeans found his physical appearance so striking that they went so far as to compare him with Jesus Christ. ${ }^{14}$ Marion Meade, describing Chatterji's appearance in 1882 , noted:

12 Pall Mall Gazette 1891.

13 Blavatsky and her associates landed in Marseilles on 12 March 1884. They lived at a house in Paris; cf. Cranston 1993: 245.

14 Even W. B. Yeats found Chatterji's appearance as similar to that of Christ. He described him as "a handsome young man with the typical face of Christ" (Yeats 1923: 113). 
He was a slender youth with thick blue-black hair falling in waves to his shoulders and magnificent velvety eyes that normally held a gentle expression. There was no mistaking his intelligence, nor overlooking the almost perfect beauty that two years hence would set aflutter the smart young women of Paris and London.

MEADE 1980: 248-249

Chatterji added to his distinctiveness and appeal by maintaining physical distance from Europeans. Blavatsky gave the impression that he was neither permitted to shake hands with men nor to look at women (Meade 1980: 296). Such gestures added to Chatterji's charm as an Oriental ascetic.

Another, even more interesting act surprised Europeans and contributed to the novel impression that Chatterji made upon them; he publicly prostrated himself before Blavatsky, lying flat on the ground and bowing his head to her, an Indian practice known in Sanskrit as dandavat-pranam (Apte 1985: 643). ${ }^{15}$ Apparently Chatterji was instructed to venerate Blavatsky publicly by Master Koot Hoomi. The purpose of doing so was to impress the European audience "externally" before making a "lasting, interior impression" (Meade 1980: 286287). He was tasked with bowing down to Blavatsky as a sign to the Western world that India respected Blavatsky for her good work and moral achievements. A letter from the Master stated, "You are the representative of India to be regenerated. You have, therefore, to show the bearing of a philosopher if you would be a chela, not that of a laughing youth" (Cranston 1993: 255). The repeated instances of his bowing down at Blavatsky's feet in London and Paris surprised the European Theosophists. To the Westerners, this action "seemed the appropriate outcoming [sic] of the profound admiration and respect" (Cranston 1993: 250) that everyone else felt toward Blavatsky. Chatterji would soon be joined in this act by his friend, the well-known British Theosophist, Bertram Keightley (1860-1949). There is one reported instance in 1884 when both of the young Theosophists bowed down at Blavatsky's feet at Charing Cross Station in London, an act that frightened the English people and that Blavatsky claimed made her angry (Blavatsky 1895: 74). Such actions — along with Chatterji's spiritual teachings - helped to cultivate an exotic identity (Dixon 2001: 31). Whether Blavatsky was really displeased by Chatterji's public prostration or was merely pretending to be angry is a different question.

15 Pranam or pranāma is a form of "a reverential salutation" (Apte 1985: 643) toward an elderly or an authoritative person. 
It is clear that such prostration was one of the public actions that the Theosophical Society wanted to display to the British audience. With such actions the Society aimed to integrate Oriental customs into Western society, and Mohini Chatterji was showcased as an ideal Oriental man. The intention was for the Society to become the chief agency in transnational engagements between Western esotericism and Oriental spirituality. However, Mohini Chatterji himself had other intentions, and these would gradually unfold over time. In order to understand this evolution, it is important to examine his activities in Europe and the United States over the next few years.

With only a few exceptions, Blavatsky took Chatterji along with her wherever she traveled during her seven-month stay in Europe in 1884. Together they visited places such as Paris and Enghien in France, Elberfeld in Germany, and Cambridge and London in the UK. The biographical accounts of Blavatsky from this period shed considerable light on Chatterji's early activities in Europe. In addition, British newspapers reported about him frequently, and there were occasional mentions of him in the Mahatma Letters as well. As a result, Mohini Chatterji's life during the mid-188os is generally well-documented.

Between March and June Blavatsky and Chatterji stayed primarily in France. The one exception was a short, week-long visit to London on the occasion of the election of the office-bearers of the London Lodge. The Madras and Calcutta branches of the Theosophical Society had sponsored Chatterji's trip to Europe in order to introduce ancient Indian wisdom to the English and French through an Indian Theosophist. It was intended that Chatterji would divide his time between London and Paris, two of the main "European centres of spiritual activity" (Barker 1924: 350). As stated in Letter 61 of the Mahatma Letters, it was thought that the occult education of the Theosophists in Paris was inferior to that of their colleagues in London. Chatterji was instructed to spend some time in Paris to provide occult education, but then to return to London once the "Continental movement [was] fairly inaugurated" (Barker 1924:350). Multiple textual sources — including the epigraph to this article confirm that most of Chatterji's Theosophical activities were scheduled in London (Blavatsky 1975: 50; Barker 1924: 471).

The period from the spring of 1884 until the end of 1885 was the most productive phase of Chatterji's Theosophical career. He spent most of this time in the UK, and his popularity reached its zenith by the end of 1885 , when he was hailed as "London's resident Indian mystic" (Meade 1980: 349). This 
was the time when Chatterji delivered most of his lectures on Theosophy and Indian philosophy, which fascinated the British occultists. Francesca Arundale - in whose house Blavatsky and Chatterji stayed for six weeks after arriving in London - would later recall that Chatterji explained Indian philosophy in eloquent words during the question and answer sessions with English audiences, which would continue until the small hours of the morning (Arundale 1915: 115). However, Chatterji later relocated to A. P. Sinnett's, where he spent most of his time during this London trip. In this period, Chatterji became actively involved with the London Lodge of the Theosophical Society, the control of which was in the hands of Sinnett. Four papers that he read at the London Lodge were published in the Theosophical Society Transactions: "Qualifications for Chelaship," "On the Higher Aspect of Theosophic Studies," "The Theosophical Society and Its Work," and "A Paper on Krishna" (Chatterji 1885a).

Around this time, Chatterji came into contact with the American Theosophist Laura Holloway, with whom he co-authored the book Man: Fragments of Forgotten History. This was one of the first transnational literary projects - collaboration between an Indian and an American Theosophist of the Theosophical Society. In this period, Holloway was seen as a promising Theosophist; William Judge wrote in a letter that her psychical abilities were comparable to that of Blavatsky herself, following which Blavatsky also considered nominating her as her successor (Cranston 1993: 257). ${ }^{16}$ So the book project of 1884 could be seen as a collaboration between two of Blavatsky's brightest pupils, in both of whom she saw great potential.

Chatterji's activities in Ireland have received the most scholarly attention (Bachchan 1965: 14-77; Kuch 1986: 14-19; Sri 1995: 61-61; Foster 1998: 469-470). The main reason for this is that Chatterji motivated two of the most prominent figures of the Irish Literary Revival, William Butler Yeats (1865-1939) and George William Russell, who wrote under the pseudonym Æ (1867-1935), to join the Theosophical Society. Inasmuch as Chatterji inspired Yeats's interest in Theosophy as well as in learning about India, any discussion of Yeats and occultism is incomplete without discussing his association with Chatterji.

16 Later, Laura Holloway did not live up to Blavatsky's expectations. For more on Holloway and her collaboration with Chatterji, see Sasson 2012. 
In early 1885, Charles Johnston, a friend of Yeats and Russell and later a bureaucrat in Bengal, read A. P. Sinnett's Esoteric Buddhism and was greatly inspired by it. He set up the Dublin Hermetic Society along with Yeats, Russell, and others, and visited Blavatsky in London. It was during this visit to London that Johnston came across Mohini Chatterji and invited him to Dublin to explain Esoteric Buddhism. ${ }^{17}$ Chatterji was himself quite fond of Sinnett's book and defended it in the pages of The Theosophist when it faced criticism from Edward von Hartmann (Chatterji 1885b: 175-77). Chatterji eventually arrived in Dublin in late 1885 , stayed there for a week, and delivered a few lectures. One of his lectures was later published in the Dublin University Review under the title "Common Sense of Theosophy" (Chatterji 1886: 24). Although Chatterji was invited to Ireland on account of his commentaries on Sinnett's work and occultism in general, he went beyond that to lecture on the Advaita Vedanta philosophy of Sankaracharya. These lectures had a profound influence on Yeats. Yeats had initially been reluctant to join the Theosophical Society and turned down Johnston's request to merge the Dublin Hermetic Society with the Theosophical Society. Nevertheless, when he attended Chatterji's lectures on Advaita Vedanta it became a turning point in his life and literary career. Yeats not only joined the Theosophical Society but also continued to romanticize India for at least the next two decades of his life.

Both Irish poets, Yeats and Russell, were highly impressed by Mohini's persona and teachings. Although, unlike Yeats, Russell "did not come under [Chatterji's] spell," he did find him to be "a very wonderful fellow" (Kuch 1986: 18). From Chatterji he received the inspiration to study Indian scriptures, and he was particularly drawn to the Bhagavad Gita, the Yoga Sutra, the GreatJewel of Wisdom, the Chandoggya Upanishad, and the Brihadaranyaka Upanishad. Peter Kuch writes that the use of words like "Soma," "Maya," and "Om" in Russell's poetry gives evidence of his attraction to the Upanishads (1986: 1418). When he learned in 1901 that his first volume of poems was being translated into Bengali, he told his American publisher, "I will come into my proper audience at last" (Denson 1962: 58).

However, it was on Yeats that Mohini Chatterji had the greatest impact. In the words of Yeats, Chatterji's lectures on the philosophy of Sankaracharya, which he delivered in Dublin, gave a shape to the vague thoughts of the young poet (1908: 191). The two were quite young when they met: Yeats was 20 years old, while Chatterji was around 27. Chatterji's lectures in Dublin can be seen as one of the starting points of Yeats's interest in occultism and Indian spirituality. As he developed a perception of mystic currents in both the West and the

17 The Dublin University Review announced that there was a possibility of Chatterji visiting Dublin towards the end of 1885 (Dublin University Review 1885: 66). 
East at a very young age, Yeats attempted to compare the traditions, and he held the view that India and pre-Christian Ireland had shared mythologies (Kuch 1986: 18). A number of poems that Yeats wrote on India were inspired by Chatterji. Among them are "Mohini Chatterji," "Kanva on Himself," "The Indian upon God," "Fergus and the Druid," and "Anashuya and Vijaya." Years later, Yeats sent a letter to Chatterji through his youngest son, Tapan Mohan, who had gone to London to study law. Although I have not found the original letter, it has been reproduced in an article written by Chatterji's great-granddaughter Rita Bandyopadhyay. This letter, written on 29 September 1935, begins as follows:

\section{Dear Mohini Chatterjee,}

I have often wondered where you were. Somebody sent me a book of yours a couple of years ago which interested me and now I have been able to get your address through a friend. I wrote merely to tell you that you are vivid in my memory after all these years. That week of talk when you were in Dublin did much for my intellect, gave me indeed my first philosophical exposition of life. When I knew you, you were a very beautiful young man; I think you were twenty-seven years old, and astonished us all, learned and simple, by your dialectical power. My wife tells me that I often quote you.

BANDYOPAD HYAY 2O13: 128-129

Along with this letter, Yeats also sent the poem which he wrote on Chatterji. It is assumed that he wrote the poem around 1928-1929, but the exact date is debated (Jain 1970: 82-96). We do not know if Chatterji ever responded to the letter and the poem. The poem, titled "Mohini Chatterji," can be seen as the most convincing evidence of Chatterji's influence on Yeats. It is mentioned in most of the discussions of Chatterji and Yeats:

I asked if I should pray.

But the Brahmin said, 'pray for nothing, say

Every night in bed, "I have been a king,

I have been a slave,

Nor is there anything.

Fool, rascal, knave,

That I have not been,

And yet upon my breast

A myriad heads have lain."' 
That he might Set at rest

A boy's turbulent days

Mohini Chatterjee

Spoke these, or words like these,

I add in commentary,

'Old lovers yet may have

All that time denied -

Grave is heaped on grave

That they be satisfied -

Over the blackened earth

The old troops parade,

Birth is heaped on Birth

That such cannonade

May thunder time away,

Birth-hour and death-hour meet,

Or, as great sages say,

Men dance on deathless feet.'

YEATS 1958: 251-252

In 1912, when Yeats met Rabindranath Tagore, he found that Tagore resembled Chatterji. Indeed, the physical similarities between the two Bengalis were striking: both had a similar style of thick, black hair, had long beards, and wore long robes.

Chatterji returned to London after his week-long stay in Dublin and spent the remainder of 1885 taking part in the activities of the London Lodge. Relations between him and Blavatsky were cordial until at least December 1885 . Blavatsky requested that her Bengali disciple write the "esoteric meaning of some of Shakespeare's plays." She wanted this for her Secret Doctrine and planned to put Mohini's name on it (Meade 1980: 380$).{ }^{18}$ Evidence suggests that Chatterji did indeed write an esoteric treatise on Hamlet: a German translation of this has survived and can be found in the Theosophical Society library in Amsterdam. At the start of 1886, however, Chatterji's relationship with Blavatsky started to deteriorate. The distance between the two would continue to grow until Mohini Chatterji resigned from the Theosophical Society.

18 However, Blavatsky did mention Chatterji in the first edition of the Secret Doctrine, volume I (published in 1888) while discussing Shankaracharya's work Viveka-Chudamani, a text that Chatterji translated into English. Interestingly, Chatterji's name disappeared from the third edition of the Secret Doctrine, published in 1893. 
By January 1886, Blavatsky realized that her dear Mohini had drifted away from her control. Chatterji had begun to have suspicions about the true nature of the Theosophical Masters. Specifically, he started to believe that the real Mahatmas "were unreachable beings who neither communicated by writing letters nor concerned themselves with worldly matters" (Meade 1980: 376377). Although he did not revolt openly against Blavatsky, he started to express his suspicions to other Theosophists, such as Francesca Arundale. According to the Mahatma Letters (Barker 1924: 477), Babaji Nath, a Theosophist from India whom Blavatsky brought to Europe in 1885 , was influencing Mohini. ${ }^{19}$ Moreover, reports about Chatterji's affairs with several British and French female Theosophists made Blavatsky furious (Meade 1980: 364-365). Chatterji's sexual encounters - which have recently received some significant scholarly attention ${ }^{20}$ - also became a subject of discussion in the British press (Shields Daily Gazette and Shipping Telegraph 1888). The Theosophical authorities, both Blavatsky and the Masters, gave up all hope for Mohini and considered him a failure (Barker 1924: 476-477). According to Blavatsky, "He was spoiled by male and female adulation, by incessant flattery and his own weaknesses" (Barker 1924: 484). It was around this time that Chatterji informed Blavatsky of his plans to visit the United States. Blavatsky was very much disturbed by the news. She thought that he might cause trouble there and "suspected it could mean the end of the Society in the United States" (Meade 1980: 377).

\section{Mohini in America}

Nevertheless, Chatterji did visit the United States, from 1886 through the autumn of $1887 .{ }^{21}$ This phase of his life has received little academic attention, which is quite surprising, considering the amount of attention his association with Yeats has received. In America, Chatterji divided his time between Boston and New York, where he was hosted by the American author Clara Erskine

19 Babaji was also known as S. Krishnaswami Iyenger or, later, as Dharbagiri Nath; URL: https://theosophy.wiki/en/Babaji (accessed 24 June 2018).

20 Rajbir Singh Judge (2018: 264-293) studies the orientalist gaze of the Western Theosophists on Chatterji's body and his sexuality. The author does not dig into his philosophical discourses, which I consider central to understanding Chatterji.

21 I am thankful to Kurt Leland for supplying me with a wealth of resources on Mohini Chatterji's visit to the United States. 
Clement Waters and the German Theosophist Arthur Gebhard respectively. The former was an acquaintance of Laura Holloway-Langford with whom Chatterji had collaborated earlier. However, it is not clear if Chatterji was still in touch with Holloway when he reached America. Holloway had already drifted away from Blavatsky by this time. Since Chatterji received hospitality from Holloway's acquaintance, perhaps he was gradually becoming part of that bloc of the Theosophical movement with which Blavatsky's relationship was cold. If that is the case, Holloway and Chatterji can be counted among the significant number of first-generation Theosophists who drifted away from Blavatsky and developed early offshoots into occult movements and alternative spiritual currents. These developments, in turn, diversified and enriched occultism's and Theosophy's discourse.

Chatterji's activities were frequently reported by the Boston Post. He was lionized and received great recognition during his stay in the United States. According to reports published in Boston Post he delivered several lectures, many of which opposed Christian missionaries. According to K. Paul Johnson (2020:11-12), Chatterji was moving closer to Unitarians and Transcendentalists in order to reunite them with the Brahmo Samaj. At this time, although he admitted that he was a member of the Theosophical Society, he claimed that he was not a Theosophist but merely a seeker, because his knowledge of the higher truth was not complete (Boston Post 1886). In any case, his activities in the United States widened his rift with Blavatsky. He and Arthur Gebhard jointly published a manifesto, "A Few Words on the Theosophical Organization," that made scathing attacks on Olcott, much to Blavatsky's annoyance (Johnson 2020: 11). Chatterji never came into contact with the Theosophical Society in Boston, an indication that his visit was not connected with the Theosophical Society or its leaders. He made this point clear also through his distinctive discourses on Advaita Vedanta. He was no longer discussing Western occultism; on the contrary, he was talking strictly from the context of Indian philosophy and India in general.

It is worth noting a newspaper report from November 1886, as it quotes Chatterji extensively and helps us to understand his standpoint at the time. Chatterji is reported to have said, "It appears to me that the time is approaching when the East will be called upon once more to furnish the religious ideal to the West. You know that all former spiritual ideals have emanated from the Orient." He further pointed out,

There is but one country in the world where the brotherhood of man is still not only thinkable but possible and that country is India ... It is because the venerable creeds of India ... have for ages taught, to a spiritually 
minded and receptive people, the ephemeral character of life, ... the chief value of which consists in the opportunities it affords for doing good.

BOSTON POST 1886

Chatterji's formulation at this point is remarkably similar to what Swami Vivekananda (1863-1902) would preach in Chicago just six years later. Chatterji's lecture tours and his discussion of Advaita Vedanta prepared the stage for the arrival of Vivekananda in America, and for this reason Chatterji should be considered the immediate pre-cursor of Vivekananda in the West. Vivekananda was not the first propagator of Advaita Vedanta and Hinduism in the West, as is commonly believed. He had predecessors, one of them being Mohini Chatterji.

\section{$9 \quad$ A Mysterious Trip to Italy}

In September 1887 Chatterji left Boston. The American press assumed that he was traveling back to India (Boston Post 1887a), but this was not the case. From America, Chatterii briefly visited London. He was still a member of the Theosophical Society and on cordial terms with at least some of the Theosophists there, including Bertram Keightley. ${ }^{22}$ Then from London he went to Italy. During the 188 os the Theosophical Society had no organizational base in Italy, ${ }^{23}$ so what was an Indian Theosophist doing there in 1887 ?

Apparently, Chatterji had learned about the existence of some ancient manuscripts in the possession of the Jesuits that resembled teachings contained in the Vedas (The Theosophist 1888). Therefore, in October 1887 he went directly from London to Rome and stayed there at least until the middle of 1888 (Shields Daily Gazette and Shipping Telegraph 1888). His stay in Italy gave rise to the rumor that he had converted to Catholicism under the influence of the Jesuits. Although it was the same Catholicism against which Chatterji was preaching in the United States only a few months before, newspapers reported that he had become a Catholic while returning from New York. ${ }^{24}$ Both Chatterji and

22 Bertram Keightley defended him in a letter to the editor of the Nottingham Evening Post (Keightley 1887).

23 For the Theosophical movement in Italy, see Pasi 2012: 81-119.

24 Shields Daily Gazette and Shipping Telegraph 1888; such reports and rumors could have arisen from the fact that just before leaving America Chatterji developed friendly relationships with Unitarians and tried to build bridges between the Brahmo Samaj and the Unitarian Church, bridges that were once started by Ram Mohan Roy; see Johnson 2020: 11-12. 
the Theosophical Society found the rumors disturbing; Chatterji wrote a letter to A. P. Sinnett in which he condemned them (Chatterji 1888). The rumors also reached Chatterji's father, Lalit Mohun Chatterji, in Calcutta, who was much disturbed by the news. The discomfort of the Theosophical Society was even greater, for two reasons: first, it now had the burden of defending one of its members with whom its relations had already grown bitter; and second, it was humiliating, for this member had allegedly developed links with one of the biggest rivals to the Theosophical Society, Christian missionaries. In response, the Theosophical Society had to publish repeated announcements in the pages of its journals, Lucifer and The Theosophist, condemning such allegations (Keightley 1888, The Theosophist 1888).

However, Chatterji's visit to Italy and the rumors that surrounded it raise a number of questions. First, who was spreading such misinformation? Was it a deliberate attempt to tarnish his image as he was gradually distancing himself from the Theosophical Society? Second, what was he actually doing in Italy for such a long time? Was he merely investigating similarities between Christian scriptures and the Vedas or did he also have other purposes? Third, what was the impact of his visit on Italian spiritual and occult scene? The answers to these questions require further research.

Chatterii returned to Calcutta in July 1888 after living in Europe and America for four years. It is difficult to ascertain the exact date when he resigned from the Theosophical Society, but he probably did so soon after his return from the West. Upon returning, he resumed his legal profession and set up a law firm called Wilson and Chatterji. He also had some involvement with Indian nationalism; he attended some of the annual sessions of the Indian National Congress, but not much is known beyond that. Chatterji's great-granddaughter mentions that he was involved with the Congress Party (Bandyopadhyay 2013: 130), and his name can be found as a delegate to the 1906 session of the Congress Party held in Calcutta. This was the session at which the partition of Bengal was a dominant subject of discussion. One can speculate that Chatterji was sympathetic to the Swadeshi movement (1905-1911) and for that reason he attended this particular session. ${ }^{25}$ Due to lack of evidence, it is difficult to

25 For locating Chatterji's name, see Indian National Congress 19o6: 148. However, he was probably not a regular attendee of the Congress sessions, as his name does not surface in the preceding and following reports of the Party's proceedings. 
comment on whether he had any interactions with the Theosophists who were involved with the Congress during the sessions he attended. However, he continued to write on Indian spirituality, particularly on Advaita Vedanta, and he became a follower of a certain North Indian mystic called Sivnarayan Swami, whose biography he published. ${ }^{26}$ Interestingly, after returning to Calcutta Chatterji became a Freemason; he was initiated into the Marine Lodge on 14 January $1889 .{ }^{27}$ However, further discussion about his post-Theosophical career is out of the scope of this article. With his return from the West, the most prominent chapter of his life came to an end, as did one of the most significant chapters in the transcultural history of the Theosophical Society.

\section{The Spiritual Universe of Mohini}

Before concluding this article, it is necessary to discuss the main tenets of Chatterji's spiritual thought. Mohini Chatterji had an excellent command of English and spoke it fluently and was a prolific writer. He also wrote poetry and short stories in English and Bengali. In his later life, Chatterji published his English poems in a weekly journal published in Calcutta. ${ }^{28}$ Although it is not an easy task, I attempted to locate most of his works preserved in Amsterdam, London, and Kolkata. Through his writings and the reports on his lectures delivered in Europe and America, it is possible to map out his spiritual discourse.

Chatterji's initial writings addressed several issues relating to occultism and Theosophy, but his main area of expertise was the exposition of Vedanta, specifically, Advaita Vedanta. He was greatly influenced by the philosophy of Sankaracharya, the well-known ninth-century philosopher who wrote commentaries on Advaita Vedanta. One of Chatterji's earliest writings was an annotated translation of Sankaracharya's philosophy titled "Discrimination of Spirit and Not-Spirit," which was published in the December $188_{3}$ issue of

26 The title of this biography is Indian Spirituality: The Travels and Teachings of Sivanarayan (Chatterji 1907).

27 See the records of Marine Lodge Calcutta, Supplement Register Folio 12, No. 232. I am thankful to Kurt Leland for providing me with this information. The reason behind Chatterji's initiation into Freemasonry is unclear and little is known about his activities as a Mason. It is possible that he joined to strengthen his social position, as many Bengali Bhadralok did during this time. Chatterji's granddaughter-in-law, Ratna Chatterji, informed me that Chatterji's elder son and grandson were also Freemasons. According to her, Chatterji and both his descendants became Grandmasters (telephone interview with Ratna Chatterji on 15 January 2018).

28 Chatterji's poems were published in multiple issues of The Calcutta Literary Review. His poetry was marked by the influence of W. B. Yeats and Rabindranath Tagore. 
The Theosophist. His philosophical expositions can also be found in a number of articles on the fundamentals of Advaita Vedanta that he read at the London Lodge. Later he would also translate Sankaracharya's Vivekachudāmani under the title The Crest Jewel of Wisdom; this text became quite popular and ran to multiple editions (Chatterji 1932).

Chatterji's best and most well-known work, however, was his translation of the Bhagavad Gita, first published in Boston in 1887 . He had already been planning to translate the Gita in late 1886, as is clear from one of his editorial opinion pieces published in the Boston Post:

I have been urged, indeed, to make new and annotated translations of some of the more important of the Eastern sacred books, such, for instance, as the Bhagavad-gita [sic]. It is possible that I may do something of the kind, if no more competent hand can be found.

BOSTON POST 1886

When Chatterji finally published the translation under the title Bhagavad Gita or the Lord's Lay in 1887, the Boston Post wrote an eloquent review of it. The newspaper considered this translation unique and different from those of Charles Wilkins and Max Müller because "it is made from the point of view of a devout scholar of religion, rather than from that of a student of literature or Sanskrit" (Boston Post 1887b). The translation was based entirely on Sankaracharya's commentary on the Bhagavad Gita. In fact, Chatterji's Gita was the first attempt by any member of the Theosophical Society to translate the entire text of the Gita. Tellingly, the Society never advertised Chatterji's translation of the Gita, nor did it republish it in a later edition. The Society did, however, enthusiastically publish discussions of short passages from the Gita by Subba Row and William Judge that date from the same year, 1887. Even later, when Annie Besant published her translation of the Bhagavad Gita, Adyar presented it as the most authentic translation and printed multiple editions (Besant 1895).

To return to Chatterji's understanding of Vedanta: he mainly echoed Sankaracharya's philosophical doctrine. He emphasized Sankara's most important philosophical formulation: "Brahma Satyam Jagan-mithya;Jivo Brahmaiva Na-para" - the Supreme Spirit (brahman) is real, the world is unreal; the individual self is nothing but the manifestation of Supreme Self. The ultimate knowledge - the gnosis - is Aham Brahmasmi, "I am the Supreme Spirit (brahman)." Chatterji's entire emphasis is on inner realization. The world, the bodily life, and physical desires are Maya, illusion or unreal. The essence of Advaita Vedanta that Mohini explained was that 
all external life and action is illusory, ephemeral, and unreal. The real life was that of dreaming, imagination, and contemplation. Only the self was worth thinking about, for all that mattered was centered in it. To go beyond the self was to leave the truth behind and to run after shadow. In brief, what appeared to be shadowy was substantial and what looked substantial was shadowy.

BACHCHAN 1965: 25

Much later, the French Traditionalist, René Guénon (1886-1951) would also be influenced by Sankaracharya's Advaita Vedanta when he would publish his Man and His Becoming According to the Vedanta in $1925 .{ }^{29}$

Mohini Chatterji's association with the Theosophical Society covered only a short period of the organization's history, and of his life. Nevertheless, it was undoubtedly one of the most important phases in regard to the development of the Theosophical Society in India and its transnational connections. When Chatterji tried to advance spiritual thought that differed from that of Blavatsky, he had to exit from the Theosophical movement. Blavatsky's domineering presence and her brand of occultism ensured that the Theosophical Society remained a movement controlled by the Western leaders.

Chatterji's challenge to the authority and ideology of Blavatsky leads to a number of unexpected conclusions. Although Blavatsky painted a romantic picture of the Orient through Theosophy, she wanted to set the tone of this Orientalism herself. As long as her disciples followed her own interpretation of Theosophy she was comfortable, but if the disciples decided to come up with their own interpretations, she became intolerant of them; Chatterji crossed this line. He showed that the Indian Theosophists could have a different perspective than Blavatsky, one that was largely molded by their own religious backgrounds. When people like Chatterji joined the Theosophical Society, they introduced their own philosophical views into Theosophical discourse.

29 There is no evidence that René Guénon ever read the works of Mohini Chatterji. Guénon's dislike for Theosophy is well known. In fact, there is much ambiguity about from where he learnt about Sankaracharya's ideas and Vedanta in general. He could not read Sanskrit and must have read Sankaracharya's works in translations. Further research is needed to understand whose translations he was reading. However, this definitely puts Chatterji and Guénon within the same circles while discussing Vedanta and occultism. 
In Chatterji's case, he brought Vedantic ideas as transmitted through the ideals of Brahmo Samaj.

While examining the conflict between Chatterji and Blavatsky, the contest for agency between them is worth highlighting. ${ }^{30}$ The power struggle and ideological battle raised the question of who speaks of Oriental spirituality with greater authenticity? Confronted with Chatterji, Blavatsky felt insecure, for she thought that he was carving out an independent career for himself as a "Mahatmic messenger" (Meade 1980: 64). She wanted Mohini to work for her mission, but he strove instead to propagate his own spiritual discourse based on Vedanta philosophy. The confrontation between the two was, in this respect, inevitable.

This power struggle and ideological conflict can be seen from two different points of view. From one point of view they can be seen as a conflict internal to the Theosophical Society. The conflict involved an Indian Theosophist trying to develop a discourse distinct from Blavatsky's Theosophical ideology. Although there have been studies of Blavatsky's conflict with Western Theosophists, namely, Elliot Coues and Anna Kingsford, not much attention has been paid to her conflict with Indian Theosophists. It can be said that the tensions between Blavatsky and her Indian followers, such as Chatterji, were different from the conflicts between Blavatsky and her Western colleagues, as the former were influenced by factors of racism and colonialism. In other words, Orientalism, both in its negative and positive forms, influenced the relationship between the Western and the Indian Theosophists. As a result, in Blavatsky's entire treatment of Chatterji as well as in his reaction, there is a racial undertone. In addition, the dynamics of their relationship also reflect his unequal position as a colonial subject. This dimension of the interrelations between the Indian and the Western members of the Theosophical Society is largely unstudied.

On this view, then, Mohini Chatterji represented the first generation of Indian Theosophists. These Theosophists raised their voices from within the Theosophical Society to express concerns that were different from those of the Society's leading authorities. Chatterji was an important representative of the Indian members who tried to negotiate with their European colleagues within the Society during the high days of British colonialism. His activities within the Theosophical movement and his relationship with the European

30 I understand the notion of "agency" here from the point of view of post-colonial studies as the ability of subjects to initiate actions in engaging or resisting authoritative power (Ashcroft, Griffiths, and Tiffin 200o: 6-7). 
and American Theosophists are embedded within the context of colonialism and its impact on the relationship between India and the Western world. Thus, colonialism stands as a vital factor in this transcultural history of occultism.

From a second point of view, the ideological battle was between Advaita Vedanta and occultism. This battle placed Mohini Chatterji in the ideological camp of Swami Vivekananda. Chatterji became a staunch supporter of Vivekananda during the 189 os and even provided financial aid for the educational project of Sister Nivedita, Vivekananda's famous Irish disciple. A number of letters written by Nivedita speak favorably of Chatterji, evidently showing that they shared cordial relations (Basu 1960: 38, 83, 96, 104, 110, 219, 387). The Theosophical Society grew out of such ideological conflicts and power struggles. In order to understand the history of the Theosophical Society in India, it is important to examine the battles for the spaces - spiritual, social, and intellectual - between Indian and Western agency. The encounters between Indian and European members is a signifier for understanding the history of spirituality within the context of colonialism. This is a major signpost for studying the transnational history of the Theosophical Society. One can argue that Chatterji's case, inasmuch as it reflects features of colonialism, Orientalism, and racism within the Theosophical movement, makes a strong argument for the use of postcolonial methodologies in research within the field of Western esotericism.

Mohini Chatterji's defection from Blavatsky's group made it clear that Indian Theosophists had views on Theosophy, occultism, and Indian spirituality that were in many ways independent of those of their Western colleagues. Chatterji was the first Indian Theosophist to diverge from the central Theosophical tenets and preach a different philosophical message, namely, Advaita Vedanta. We can see a very similar process in the case of Jiddu Krishnamurti, who would dissociate from the Theosophical Society and carve out an independent career. Certainly, Krishnamurti became more successful and famous than Chatterji; nevertheless, Chatterji had already set the precedent. Although the contexts of these two Indian Theosophists differed, it might be a good idea to situate them within the same frameworks and trajectories of thought and action. Mohini Chatterji is an important missing link in the history of occultism and modern Indian spirituality who exercised significant agency in the Theosophical Society's transnational exchanges. His case serves as a model for investigating the role and position of Indian members within the Theosophical movement and that movement's power structures. 


\section{Acknowledgments}

I am grateful to Wouter J. Hanegraaff, Marco Pasi, Karl Baier, Julie Chajes, Christian Greer, and the anonymous reviewers for their comments on earlier versions of the article. Thanks are also due to the family members of Mohini Chatterji, namely, Monojit Chatterji, Rita Bandyopadhyay, and Ratna Chatterji, for providing important information. All three of them were interviewed either in person or via telephone and, therefore, this article engages oral history as a method of research.

\section{References}

Akai, Toshio. 1997. "On the Early Writings of AE and the Theosophical Movement of Dublin Lodge." The Harp 12: 75-89.

Apte, Vaman Shivram (ed.). 1985. The Practical Sanskrit-English Dictionary, 4th ed. Delhi: Motilal Banarsidass.

Arundale, Francesca. 1915. "In Memorium - H. P. Blavatsky." The Herald of the Star 4:115.

Ashcroft, Bill, Gareth Griffiths, and Helen Tiffin (eds.). 20oo. Post-Colonial Studies: The Key Concepts. 2nd ed. London: Routledge.

Bachchan, H. R. 1965. W. B. Yeats and Occultism. Delhi: Motilal Banarsidass.

Bandyopadhyay, Rita. 2013. "Mahat Praan Mohini Mohun Chattopadhyay." Baha 7: $125^{-134 .}$

Barker, A. Trevor (ed.). 1924. The Mahatma Letters to A. P. Sinnett. London: T. Fisher Unwin.

Basu, Sankari Prasad (ed.). 196o. Letters of Sister Nivedita, Vol. 1. Calcutta: Nababharat Publishers.

Besant, Annie. 1895. The Bhagavad Gita or the Lord's Song. London: Theosophical Publishing Society.

Blavatsky, Helena Petrovna. 1883. "Chelas and Lay Chelas." The Theosophist (supplement) 4(10): 10-11.

Blavatsky, Helena Petrovna. 1895. "Letters of H. P. Blavatsky." The Path 10(3): 73-79.

Blavatsky, Helena Petrovna. 1969. Collected Writings, Vol. 4. Boris de Zirkoff (comp.). Wheaton, IL: Theosophical Publishing House.

Blavatsky, Helena Petrovna. 1975. The Letters of H. P. Blavatsky to A. P. Sinnett. A. Trevor Barker (comp.). Pasadena, CA: Theosophical University Press.

Boston Post. 1886. "Theosophy's Apostle: Babu Mohini Mohun Chatteryi in Boston." Boston Post, 29 November: 2.

Boston Post. 1887a. "Personal." Boston Post, 24 September: 2. 
Boston Post. 1887b. "Mr. Mohini's ‘The Bhagavad Gita.'” Boston Post, 11 November: 5 .

Chatterji, Mohini M. 1883. "The Himalayan Brothers: Do They Exist?" The Theosophist 5(51): $115^{-118 .}$

Chatterji, Mohini M.1885. Transactions of the London Lodge of the Theosophical Society. London: Theosophical Publishing House.

Chatterji, Mohini M. 1885b. "Edward von Hartmann's Criticism of Esoteric Buddhism." The Theosophist 6(68): 175-177.

Chatterji, Mohini M. 1886. "Common Sense of Theosophy." Dublin University Review 2(5): 24 .

Chatterji, Mohini M. 1888. "To the President of the London Lodge of the Theosophical Society." Lucifer 1(6): 506 .

Chatterji, Mohini M. 1907. Indian Spirituality: The Travels and Teachings of Sivanarayan. London: J. M. Dent \& Sons.

Chatterji, Mohini M. 1932. Vivekachudamani or the Crest Jewel of Wisdom of Sri Sankaracharya. Adyar: Theosophical Publishing House.

Chatterji, Mohini M. and Laura Holloway. 1893. Man: Fragments of Forgotten History, 3rd ed. London: Reeves and Turner.

Chaudhurani, Sarala Devi. 2007 Jiboner Jharapata. Calcutta: Dey's Publishers.

Cranston, Sylvia. 1993. HPB: The Extraordinary Life and Influence of Helena Blavatsky, Founder of the Modern Theosophical Movement, 2nd ed. New York: G. R. Putnam's Sons.

Dasgupta, Subrata. 2009. The Bengal Renaissance. Calcutta: Permanent Black.

Denson, Alan (ed.). 1962. Letters from A. E. London: Abelard-Schuman.

Dixon, Joy. 2001. Divine Feminine: Theosophy and Feminism in England. Baltimore: The Johns Hopkins University Press.

Foster, R. F. 1998. W. B. Yeats: A Life, Vol. 1. New York: Oxford University Press.

Hanegraaff, Wouter J. 1996. New Age Religion and Western Culture: Esotericism in the Mirror of Secular Thought. Leiden: E. J. Brill.

Hurwitz, Harold M. 1964. "Yeats and Tagore." Comparative Literature 16: 55.

Indian National Congress. 1906. Report on the Proceedings of the Twenty-Second Indian National Congress. Calcutta.

Jain, Sushil Kumar. 1970. "Indian Elements in the Poetry of Yeats: On Chatterji and Tagore." Comparative Literature Studies 7(1): 82-96.

Johnson, K. Paul. 2020. "Theosophy in the Bengal Renaissance." In Tim Rudbøg and Erik Sand (eds.), Imagining the East: The Early Theosophical Society, New York: Oxford University Press.

Judge, Rajbir Singh. 2018. "Dusky Countenances: Ambivalent Bodies and Desires in the Theosophical Society." Journal of the History of Sexuality 27(2): 264-293.

Keightley, Bertram. 1887. "Mr. Mohini." Nottingham Evening Post, 8 November: 2. Keightley, Bertram. 1888. “To the Editors.” Lucifer 1(6): 506. 
Kopf, David. 1969. British Orientalism and Bengal Renaissance. Berkeley: University of California Press.

Kopf, David. 1979. The Brahmo Samaj and the Shaping of the Modern Indian Mind. Princeton, NJ: Princeton University Press.

Kuch, Peter. 1986. Yeats and AE: "the Antagonism that Unites Dear Friends." London: Barnes and Noble.

Liverpool Mercury. 1884. "Our London Correspondence." The Liverpool Mercury, 3 October: 5 .

Meade, Marion. 1980. Madame Blavatsky: The Woman Behind the Myth. New York: G. R. Putnam's Sons.

Mukhopadhyay, Mriganka. 2016. "A Short History of the Theosophical Movement in Bengal." In Makhanlal Roycowdhury (ed.), Paralok-tattwa, 2nd ed., Kolkata: Bengal Theosophical Society, 101-134.

Nottingham Evening Post. 1887. "Mr. Mohini." The Nottingham Evening Post, 28 October: 5 .

Olcott, Henry Steel. 1900. Old Diary Leaves: The Only Authentic History of the Theosophical Society, Vol. 2. London: Theosophical Publishing Society.

Olcott, Henry Steel. 1904. Old Diary Leaves: The Only Authentic History of the Theosophical Society, Vol. 3. London: Theosophical Publishing Society.

Pall Mall Gazette. 1891. "The Blavatsky Season in London." Pall Mall Gazette, 11 May: 2.

Pasi, Marco. 2012. "Theosophy and Anthroposophy in Italy during the First Half of Twentieth Century." Theosophical History 16(2): 81-119.

Sarkar, Sushabhan Chandra. 1979. On the Bengal Renaissance. Bombay: People's Publishing House.

Sasson, Diane. 2012. Yearning for the New Age: Laura Holloway-Langford and Late Victorian Spirituality. Bloomington: Indiana University Press.

Sen, Amit. 1946. Notes on Bengal Renaissance. Bombay: People's Publishing House.

Shields Daily Gazette and Shipping Telegraph. 1888. “Tea Table Talk.” The Shields Daily Gazette and Shipping Telegraph, 22 March: 3.

Sri, P. S. 1995. "Yeats and Mohini Chatterji." In William Gould (ed.), Yeats Annual n1, New York: St Martin's Press, 61-76.

The Theosophist. 1883. "The First Anniversary of the Bengal Theosophical Society." The Theosophist (supplement) 4(10):1-2.

The Theosophist. 1888. "Babu Mohini M. Chatterji." The Theosophist 9(106): xivii.

Travers, Robert. 2007. Ideology and Empire in Eighteenth-Century India: The British in Bengal. Cambridge: Cambridge University Press.

Yeats, W. B. 1958. Collected Poems of W. B. Yeats. London: Macmillan.

Yeats, W. B., and Allan Wade. 19o8. Collected Works in Verse and Prose, Vol. 7. London: Shakespeare Head Press. 